www.jmscr.igmpublication.org

Impact Factor 5.84

Index Copernicus Value: 83.27

ISSN (e)-2347-176x ISSN (p) 2455-0450

crossref DOI: _https://dx.doi.org/10.18535/jmscr/v5i4.167

Journal Of Medical Science And Clinical Research

\title{
Study of Serum Vitamin D Level among Critically Ill Patients Admitted to Alexandria University Pediatric Intensive Care Unit
}

\author{
Authors \\ Amina SdqyAl Halwany ${ }^{1}$, Akram Abd Elmoneim Deghady², \\ Azza Ahmad Ahmad Moustafa ${ }^{1}$, Asmaa Elgebaly Mahrous Diab ${ }^{1}$ \\ ${ }^{1}$ Pediatrics Department, Faculty of Medicine, Alexandria University, Egypt \\ ${ }^{2}$ Clinical Pathology Department, Faculty of Medicine, Alexandria University, Egypt
}

\begin{abstract}
Background: Vitamin D is a pleiotropic hormone that plays an important role in calcium homeostasis, bone health, cardiovascular system and immunity. Vitamin D has other roles in the body, including modulation of cell growth, neuromuscular and immune functions, and reduction of inflammation. Its deficiency may aggravate the incidence and outcome of infectious complications in critically ill patients.

Aim: The aim of this work was to determine the frequency of vitamin $D$ deficiency in critically ill patients admitted to pediatric intensive care unit [PICU], Alexandria university children's hospital (AUCH) and relate the state of serum 25(OH) D to disease severity.

Methods: Study was carried out on 102 critically ill children admitted to PICU at AUCH. Blood was collected on PICU admission and analyzed for 25(OH) D concentration by using enzyme linked immunosorbent assay (ELISA) kits.

Results: Low vitamin D levels had been found in most of our patients where $37.3 \%$ of cases were vitamin D deficient and $38.2 \%$ of cases were vitamin D insufficient while only $24.5 \%$ of cases were vitamin D sufficient. High Pediatric logistic organ dysfunction (PELOD) score and high alkaline phosphatise (ALP) were associated with 25(OH)D deficiency while summer season and sun exposure were protective. There was no significant difference according to vitamin D level as regards PICU stay, patient mortality, presence of sepsis or septic shock and main affected system on admission.

Conclusion: We found a high rate of vitamin $D$ deficiency in critically ill children and vitamin $D$ level was negatively correlated with PELOD score. We recommend screening of critically ill children for vitamin $D$ deficiency to restore their serum levels.
\end{abstract}

\section{Introduction}

Vitamin D is a fat-soluble vitamin, normally produced in skin through a robust photolytic process acting on a derivative of cholesterol (7dehydrocholesterol) to produce previtamin $\mathrm{D}$, which is then slowly isomerized to vitamin D3 (the natural form of vitamin D). ${ }^{(1)}$
Vitamin D promotes calcium absorption in the gut and maintains adequate serum calcium and phosphate concentrations to enable normal mineralization of bones and to prevent hypocalcemictetany. It is also needed for bone growth and bone remodeling by osteoblasts and osteoclasts. $^{(2,3)}$ 
Vitamin D has other roles in the body, including modulation of cell growth, neuromuscular and immune functions, and reduction of inflammation. ${ }^{(2,45)}$ Many genes encoding proteins that regulate cell proliferation, differentiation, and apoptosis are modulated in part by vitamin D. ${ }^{(2)}$ Many cells have vitamin $\mathrm{D}$ receptors, and some convert $25(\mathrm{OH}) \mathrm{D}$ to $1,25(\mathrm{OH})_{2} \mathrm{D}$. It is now recognized that not only the kidneys have the ability to produce $1,25(\mathrm{OH})_{2} \mathrm{D}$ but also a wide variety of other tissues, cells and organs have the enzymatic machinery. ${ }^{(6,7)}$

The $25(\mathrm{OH}) \mathrm{D}$ level in the serum is the best indicator of vitamin D status. Patients with levels $<20 \mathrm{ng} / \mathrm{mL}$ are commonly categorized as vitamin D deficient ${ }^{(8-10)}$ while, children with $25(\mathrm{OH}) \mathrm{D}$ levels $<30 \mathrm{ng} / \mathrm{mL}$ are considered to be insufficient. ${ }^{(10,11)}$

Vitamin D plays a key role in immune functions. Its deficiency may aggravate the incidence and outcome of infectious complications in critically ill patients. ${ }^{(12)}$

Vitamin D deficiency has been associated with higher levels of admission ill nessseverity in adult intensive care unit [ICU] patients. ${ }^{(13,14)}$ Critically ill adult patients with sepsis have lower vitamin D levels. $^{(15)}$

Though high prevalence of vitamin D deficiency in critically ill adults and children has been documented, the impact of such deficiency is not yet clear. Few studies have documented significant association of deficiency with poor outcomes such as longer duration of ICU stay ${ }^{(16,}$

17), increased inotropic requirement ${ }^{(18,19)}$ and higher admission illness severity scores $(16,20)$

\section{Subjects and Methods \\ Subjects}

In this prospective observational clinical study, our sample size was 90 cases as assigned by biostatistics department in high institute of health, Alexandria University. One hundred and ten patients admitted to PICU in AUCH were included and investigated for serum vitamin D level at the time of admission. Eight patients were excluded from the study due to insufficient samples. We investigated the relation between serum $25(\mathrm{OH})$ D level and important clinical outcomes including PICU stay and patient mortality as well as risk factors for its deficiency. Inclusion criteria included the followings: (1) Patients aged $>1$ month to $\leq 5$ years. (2) PICU stay $>48$ hours. Exclusion criteria included the followings: (1) Patients aged $<1$ month and $>5$ years. (2)Patients remain in PICU <48 hours. (3) Patients with metabolic disease affecting vitamin D metabolism as Hypo/hyperparathyroidism, bone disease or malignancy. (4) Surgical patients.

All the parents or the legal guardians of the patients enrolled in this study signed a written informed consent before participation. The study was approved by the Medical Ethics Committee of the Faculty of Medicine, Alexandria University.

\section{Methods}

All patients were subjected to full history taking, thorough clinical examination and laboratory investigations including complete blood picture, urea, Creatinine, calcium, phosphorus, alkaline phosphatase (ALP), total protein, albumin and cultures of blood and urine. Samples for serum 25 $(\mathrm{OH})$ D levels were taken on PICU admission. Samples were centrifuged at $1,000 \mathrm{~g}\left(4^{\circ} \mathrm{C}, 15\right.$ minutes) and serum was stored at $-80^{\circ} \mathrm{C}$ until analysis. The test was done by using commercial enzyme linked immunosorbent assay (ELISA) kits (DLD Diagnostika GmbH, Hamburg, Germany) according to the manufacturer's instructions. ${ }^{(21)}$ Pediatric mortality and prognostic scores were calculated (Pediatric index of mortality(PIM)2 upon admission and Pediatric logistic organ dysfunction (PELOD) after the first 24 hours of admission).

\section{Results}

We screened 102 patients whose ages ranged from 1.3 to 50 months with a mean of $9.53 \pm 10.57$ months. Vitamin D levels varied among patients from 3.0 to $60.0 \mathrm{ng} / \mathrm{ml}$ with a mean of $23.18 \pm$ $12.49 \mathrm{ng} / \mathrm{ml} ; 37.3 \%$ of patients were vitamin $\mathrm{D}$ 
deficient (VDD) $(<20 \mathrm{ng} / \mathrm{ml}), 38.2 \%$ had vitamin D insufficiency $(20-29.9 \mathrm{ng} / \mathrm{ml})$ and $24.5 \%$ had normal vitamin D level (>30 ng/ml).(Figure 1)

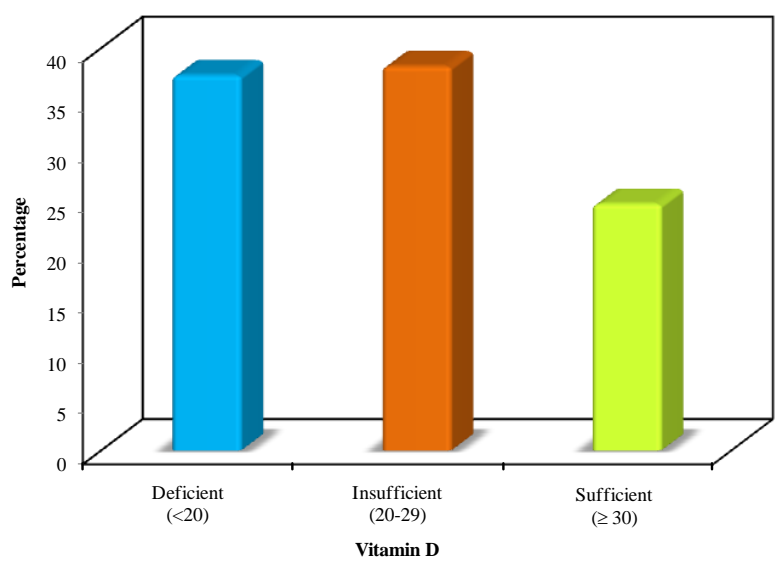

Figure (1): Distribution of the studied cases according to vitamin D level

Samples from $52 \%$ of the patients were taken in the autumn/winter seasons (from 1 September till 28 February), while $48 \%$ of the samples were taken in spring/summer seasons (from 1 March till 31 August). Serum vitamin D levels were significantly lower in blood samples withdrawn during autumn/winter than those in spring/summer $(p=0.001)$. (Figure 2)Inadequate sun exposure was significantly associated with lower vitamin D levels $(81.6 \%$ of VDD patients showed history of inadequate sun exposure) ( $p=0.041)$. (Figure 3 )

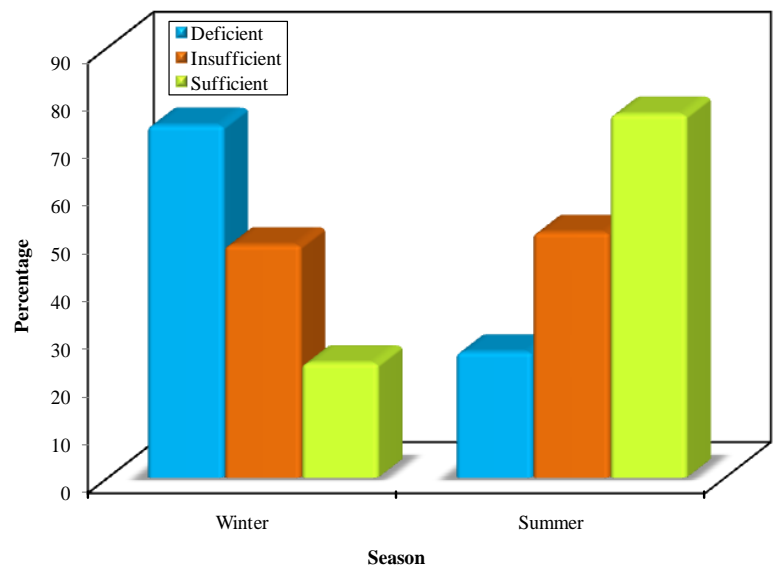

Figure (2): Relation between vitamin D and season

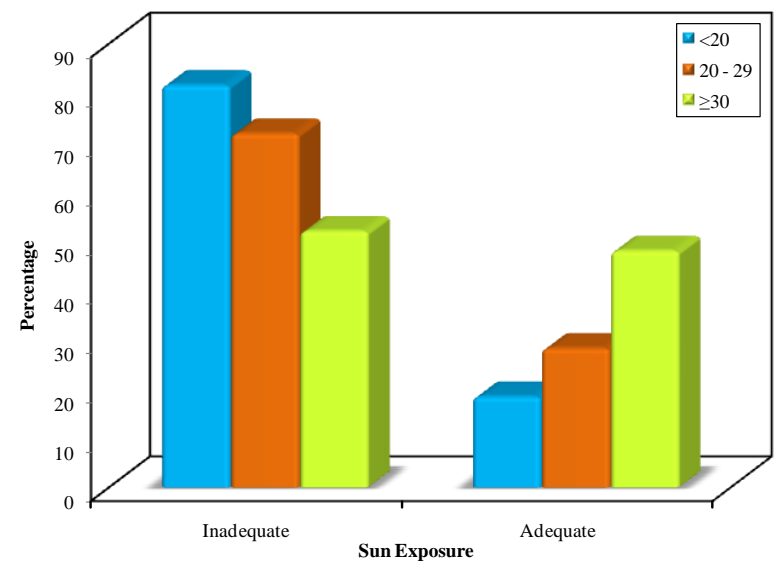

Figure (3): Relation between vitamin D and sun exposure

Despite majority of VDD and insufficient patients were breast fed (52.6\%, 53.8\% respectively), there was no statistically significant difference between vitamin D level on admission and type of feeding $\left({ }^{M C} p=0.065\right)$.

Correlations between vitamin D and different parameters are showed in table (1).

We found that vitamin D level was negatively correlated to PELOD score, where VDD patients had the highest PELOD score with a mean of $16.74 \pm 6.68$ then vitamin $D$ insufficient patients with a mean of $12.16 \pm 10.71$, while vitamin D sufficient patients had the lowest PELOD score with a mean of $5.04 \pm 8.58(p<0.001)$.

There was no correlation between vitamin D level and PIM2 score, where VDD patients had PIM 2 score with a mean of $39.74 \pm 26.95$, vitamin D insufficient patients had a mean of $39.24 \pm$ 34.05, while vitamin D sufficient patients had a mean of $44.62 \pm 23.19$ ( $p=0.732)$.

According to patients mortality, there was no statistically significant difference between vitamin $D$ level on admission and patient mortality $(p=0.442)$.

The mean length of PICU stay in VDD patients was $8.0 \pm 5.99$ days, in vitamin $\mathrm{D}$ insufficient patients was10.56 \pm 15.80 days, while it was $10.24 \pm 8.95$ days in vitamin $D$ sufficient. There was no statistically significant difference between vitamin D level on admission and length of PICU stay $(p=0.448)$. 
There was no statistically significant difference between vitamin $\mathrm{D}$ level and septic shock or sepsis. ( $p=0.064, p=0.355$ respectively)

Regarding affected system, vitamin D deficiency did not show any predilection to specific system $\left({ }^{M C} p=0.825\right)$.

Among laboratory investigations, low vitamin D levels were negatively correlated to high ALP levels ( $p=0.023$ ).

Regarding serum CRP ; VDD patients had a mean of $142.93 \pm 81.04 \mathrm{mg} / \mathrm{l}$, vitamin $\mathrm{D}$ insufficient patients had a mean of $44.34 \pm 53.58 \mathrm{mg} / \mathrm{l}$ while vitamin $\mathrm{D}$ sufficient patients had a mean of 45.20 $\pm 33.40 \mathrm{mg} / \mathrm{l}$. There was a negative correlation between vitamin $\mathrm{D}$ levels on admission and serum C- reactive protein (CRP) $(p<0.001)$.

Regarding serum albumin; VDD patients had a mean of $3.03 \pm 0.75 \mathrm{~g} / \mathrm{dl}$, vitamin $\mathrm{D}$ insufficient patients had a mean of $3.13 \pm 0.63 \mathrm{~g} / \mathrm{dl}$ while vitamin D sufficient patients had a mean of $3.10 \pm$ $0.55 \mathrm{~g} / \mathrm{dl}$. There was no a statistically significant difference between vitamin $\mathrm{D}$ levels on admission and serum albumin $(p=0.960)$.

Regarding serum uric acid, there was no statistically significant difference between vitamin D level and serum uric acid ( $p=0.436)$.

Table (1) Correlation between Vitamin D with different parameters

\begin{tabular}{|l|c|c|}
\hline \multirow{2}{*}{} & \multicolumn{2}{|c|}{ Vitamin D } \\
\cline { 2 - 3 } & $\mathrm{r}_{\mathrm{s}}$ & $\mathrm{p}$ \\
\hline Age & 0.153 & 0.125 \\
\hline Weight for age & $0.199^{*}$ & 0.045 \\
\hline PIM2 & 0.034 & 0.732 \\
\hline PELOD & $-0.491^{*}$ & $<0.001$ \\
\hline Length of PICU stay & 0.108 & 0.282 \\
\hline Septic Shock & -0.184 & 0.064 \\
\hline Sepsis & -0.092 & 0.355 \\
\hline CRP & $-0.542^{*}$ & $<0.001$ \\
\hline Alb & -0.010 & 0.921 \\
\hline Ph & 0.001 & 0.991 \\
\hline ALP & $-0.226^{*}$ & $0.023^{*}$ \\
\hline Total Ca & 0.063 & 0.529 \\
\hline Ionized Ca & 0.012 & 0.908 \\
\hline
\end{tabular}

$\mathrm{r}_{\mathrm{s}}$ : Spearman coefficient

*: Statistically significant at $\mathrm{p} \leq 0.05$

\section{Discussion}

We found a high percentage of vitamin D deficiency and insufficiency among critically ill patients in our PICU; (37.3\%)of patients were vitamin $\mathrm{D}$ deficient $(<20 \mathrm{ng} / \mathrm{ml}),(38.2 \%)$ had vitamin D insufficiency (20-29.9 $\mathrm{ng} / \mathrm{ml})$ and $(24.5$ $\%$ ) had normal vitamin D levels (>30 ng/ml). In agreement with our results, Madden et al (20), studied 511 critically ill children admitted to Boston Children's Hospital PICU. They found a high rate of vitamin D deficiency in their critically ill children as $40.1 \%$ of cases were vitamin D deficient. In addition, Rey et al ${ }^{(19)}$ studied 156 PICU patients (in comparison with 289 healthy children regarding their $25 \mathrm{OH} \mathrm{D}$ levels and they found that the incidence of vitamin D deficiency was higher in the PICU population.

Sun exposure and summer/spring seasons were found to be protective factors against vitamin $\mathrm{D}$ deficiency. In accordance with our results, Madden et $\mathrm{al}^{(20)}$ found higher 25(OH)D levels in patients admitted during summer. Meena et $\mathrm{al}^{(22)}$ showed that there was a positive correlation between afternoon sunlight exposure and infant's vitamin D levels in their patients in a tertiary care hospital in Delhi.

Vitamin D deficiency is presumed to increase morbidity and mortality by its pleiotropic effects on various organ system functions and its effects on innate and adaptive immunity. ${ }^{(23)}$ In this context, we found that vitamin D levels were negatively correlated to PELOD score. Also, Sankar et $\mathrm{al}^{(24)}$ observed that children who were vitamin $\mathrm{D}$ deficient at admission were more likely to have higher organ dysfunction scores, although the differences were not statistically significant.

There was no statistically significant difference between vitamin D level and PIM2 score. In accordance to our result, Sankar et al ${ }^{(24)}$ and Rey et al ${ }^{(19)}$ reported no significant relation between them.

There was no statistically significant difference between vitamin $\mathrm{D}$ level on admission and length of PICU stay. This was in agreement with 
Ponnarmeni et al ${ }^{(25)}$ who found that VDD had no significant effect on length of PICU stay.

In our study, there was no statistically significant difference between vitamin D level on admission and mortality. Also in Ponnarmeni et al ${ }^{(25)}$ study; VDD had no significant effect on mortality.

Regarding affected system, vitamin D deficiency did not show any predilection to specific system. Similarly, Sankar et al ${ }^{(24)}$ found that there was no significant relation between vitamin $\mathrm{D}$ level and the main affected system on admission.

In the present study, there was no statistically significant relation between vitamin D level and septic shock or sepsis. In accordance to us, Shah et al (26) found that there was no statistically significant difference as regard diagnosis of sepsis or septic shock on admission in patient with VDD. In contrast, Ponnarmeni et al ${ }^{(25)}$ demonstrated that the prevalence of VDD among critically ill children with sepsis was $50.8 \%$, which was significantly higher than in healthy controls (40.2\%) and found that patients with VDD had an increased incidence of shock, although the difference was not statistically significant.

\section{Conclusion}

Based on the results of the present study, we found a high rate of vitamin $D$ deficiency in critically ill children and vitamin D level was negatively correlated with PELOD score. We also found a protective effect of sun exposure. We recommend screening of those critically ill children with risk factors for vitamin D deficiency to restore their serum levels in order to improve their outcome.

\section{References}

1. Holick MF. High prevalence of vitamin D inadequacy and implications for health. Mayo ClinProc2006; 81(3):353-73.

2. Ross AC, Taylor CL, Yaktine AL, Del Valle HB. Dietary Reference Intakes for Calcium and Vitamin D. Washington (DC): National Academies Press (US); 2011. Available from: http://www. ncbi.nlm. nih. gov /books/NBK56070/.last access at (24/11/2014).

3. Cranney A, Horsley T, O'Donnell S, Weiler H, Puil L, Ooi D, et al. Effectiveness and safety of vitamin D in relation to bone health. Evid RepTechnol Assess (Full Rep) 2007; (158):1-235.

4. Holick MF. Vitamin D. In: Shils ME, Shike M, Ross AC, Caballero B, Cousins RJ , (eds). Modern Nutrition in Health and Disease, $10^{\text {th }}$ ed. Philadelphia: Lippincott Williams \& Wilkins; 2006. 378-93.

5. Norman AW, Henry HH. Vitamin D. In: Bowman BA, Russell RM, (eds). Present Knowledge in Nutrition, $9^{\text {th }}$ ed. Washington DC: ILSI Press; 2006. 199-214.

6. Jones G. Expanding Role for Vitamin D in chronic kidney disease: importance of blood 25-OH-D levels and extra-renal $1 \alpha-$ hydroxylase in the classical and non classical actions of $1 \alpha, 25$ - dihydroxyvitamin D3. Semin Dial 2007;20(4): 316-24.

7. Bikle D. Non classic actions of vitamin D. J ClinEndocrinolMetab 2009; 94(1):2634.

8. Misra M, Pacaud D, Petryk A, Collett Solberg PF, Kappy M. Vitamin D deficiency in children and its management: review of current knowledge and recommendations. Pediatrics 2008; 122 (2):398-417.

9. Gordon CM, Feldman HA, Sinclair L, Kleinman PK, Perez-Rossello J. Prevalence of vitamin D deficiency among healthy infants and toddlers. Arch Pediatr Adolesc Med 2008; 162(6):505-12.

10. Saintonge S, Bang H, Gerber LM. Implications of a new definition of vitamin $\mathrm{D}$ deficiency in a multiracial us adolescent population: the National Health and Nutrition Examination Survey III. Pediatrics 2009; 123(3):797-803.

11. Gordon CM, DePeter KC, Feldman HA, Grace E, Emans SJ. Prevalence of vitamin D deficiency among healthy adolescents. 
Arch Pediatr Adolesc Med 2004; 158(6):531-7.

12. Ginde AA, Mansbach JM, Camargo CA Jr. Association between serum 25hydroxyvitamin $\mathrm{D}$ level and upper respiratory tract infection in the third national health and nutrition examination survey. Arch Intern Med 2009; 169(4):384-90.

13. Amrein K, Zajic P, Schnedl C, Waltensdorfer A, Fruhwald S, Holl A, et al. Vitamin D status and its association with season, hospital and sepsis mortality in critical illness. Crit Care 2014; 18(2): R47.

14. McKinney JD, Bailey BA, Garrett LH, Peiris P, Manning T, Peiris AN. Relationship between vitamin $\mathrm{D}$ status and ICU outcomes in veterans. J Am Med DirAssoc 2011; 12(3):208-11.

15. Braun AB, Gibbons FK, Litonjua AA, Giovannucci E, Christopher KB. Low serum 25-hydroxyvitamin D at critical care initiation is associated with increased mortality. Crit Care Med 2012; 40(1):6372.

16. McNally JD, Menon K, Chakraborty $\mathrm{P}$, Fisher L, Williams KA, Al-Dirbashi OY, et al. The association of vitamin D status with pediatric critical illness. Pediatrics 2012;130:429-36.

17. Padhi R, Panda B, Jagati S, Patra SC. Vitamin D status in adult critically ill patients in Eastern India: an observational retrospective study. Lung India 2014;31:212-6.

18. Rippel C, South M, Butt WW, Shekerdemian LS. Vitamin D status in critically ill children. Intensive Care Med 2012;38:2055-62.

19. Rey C, Sánchez-Arango D, López-Herce J, Martínez-Camblor P, García-Hernández I, Prieto B, et al. Vitamin D deficiency at pediatric intensive care admission. $\mathrm{J}$ Pediatr (Rio J). 2014;90:135-42.
20. Madden K, Feldman HA, Smith EM, Gordon CM, Keisling SM, Sullivan RM, et al. Vitamin D deficiency in critically ill children. Pediatrics 2012;130:421-8.

21. Krika LJ. Principles of immune chemical techniques. In: Burtis CA, Ashwood ER, (eds). Tietz textbook of clinical chemistry and molecular diagnostics. $5^{\text {th }}$ ed. St Louis: Elsevier Saunders Co; 2012. 219-44.

22. Meena P, Dabas A, Shah D, Malhotra RK, Madhu SV, Gupta P. Sunlight Exposure and Vitamin D Status in Breastfed Infants.Indian Pediatr 2017; 54:105-11.

23. Samuel S, Sitrin MD. Vitamin D's role in cell proliferation and differentiation. Nutr Rev. 2008 Oct;66(10):S116-24.

24. Sankar J, Lotha W, Ismail J, Anubhuti C, Meena RS, Sankar MJ, et al. Vitamin D deficiency and length of pediatric intensive care unit stay: a prospective observational study. Ann Intensive Care. 2016;6(1):3

25. Ponnarmeni S, Kumar Angurana S, Singhi S, Bansal A, Dayal D, Kaur R,et al. Vitamin D deficiency in critically ill children with sepsis. PaediatrInt Child Health 2016;36(1):15-21.

26. Shah SK, Kabra SK, Gupta N, Pai G, Lodha R. Vitamin D Deficiency and Parathyroid Response in Critically-ill Children: Association with Illness Severity and Clinical Outcomes. Indian Pediatr 2016; 53(6):479-84. 